\title{
Emission Factor of Carbon Dioxide from In-Use Vehicles in Thailand
}

\author{
Sutthicha Nilrit ${ }^{1} \&$ Pantawat Sampanpanish ${ }^{2}$ \\ ${ }^{1}$ Environmental Science (Interdisciplinary program) Graduate School, Chulalongkorn University, Bangkok, \\ Thailand \\ ${ }^{2}$ Environmental Research Institute, Chulalongkorn University, Bangkok, Thailand \\ Correspondence: Pantawat Sampanpanish, Environmental Research Institute, Chulalongkorn University, \\ Phyathai Road, Pathumwan, Bangkok 10330, Thailand. Tel: 66-2-218-8219. E-mail: pantawat.s@chula.ac.th
}

Received: July 2, $2012 \quad$ Accepted: July 22, $2012 \quad$ Online Published: July 27, 2012

doi: 10.5539/mas.v6n8p52 URL: http://dx.doi.org/10.5539/mas.v6n8p52

\begin{abstract}
The objective of determining the emission factor of carbon dioxide $\left(\mathrm{EF}-\mathrm{CO}_{2}\right)$ from in-use vehicles in Thailand is to gather important data for estimating transport emissions. These data may help develop greenhouse gas management plans for the area. In-use vehicles were tested on a chassis dynamometer by the Bangkok Driving Cycle to quantify $\mathrm{CO}_{2}$ emissions. The emission factor is defined as the average emission rate for $\mathrm{CO}_{2}$ per vehicle based on average speed and fuel consumption. The studied vehicle types were the following: heavy duty diesel vehicles (HDDV); light duty diesel vehicles (LDDV); light duty gasoline vehicles (LDGV); and motorcycles (MC) with 4-stroke engines. These vehicles were tested using a variety of fuel types available in Thailand. The study result was found that emissions from the vehicle types were significantly different at the statistic of $\mathrm{p}$-value $<0.05$. These results can be compared with emission factors of $\mathrm{CO}_{2}$, including the vehicle types and fuel types from international studies and used in Thailand to promote better efficiency to mitigate greenhouse gas emissions from vehicles.
\end{abstract}

Keywords: emission factor, greenhouse gas, carbon dioxide $\left(\mathrm{CO}_{2}\right)$, in-use vehicles

\section{Introducation}

Concentrations of carbon dioxide $\left(\mathrm{CO}_{2}\right)$, a greenhouse gas (GHG) produced by in-use vehicles, have been increasing in large cities (IPCC, 1995). These emissions are the result of fossil fuel combustion (IPCC, 2007). Developing countries are responsible for an increasing proportion of $\mathrm{CO}_{2}$ emissions from transport-related activities (Wang, 2010). The number of vehicles and the rate of fuel use in Thailand have increased rapidly, resulting in ever higher emissions of $\mathrm{CO}_{2}$ and other pollutants. Studies of vehicles in Thailand have focused on calculating fuel consumption and other data. The main objective of this study was to determine the emission factor of $\mathrm{CO}_{2}$ for vehicles in Thailand. The study investigated heavy duty diesel vehicles (HDDV), light duty diesel vehicles (LDGV), light duty gasoline vehicles (LDGV), and two wheels-motorcycles and three-wheels (tuk-tuks) with four stroke engines (MC). The results were compared with engines operating with alternative fuels in Thailand, including varieties of biodiesel (BX), compressed natural gas (NGV and CNG) and liquefied petroleum gas (LPG). The results can be used to assess means of improving air quality in the megacities of Thailand by reducing and managing $\mathrm{CO}_{2}$ emissions from vehicle sources.

\section{Method}

\subsection{The Experimental Procedures}

This study focused on of four types and engines capacity of vehicles in Thailand: heavy duty diesel vehicles (HDDV), light duty diesel vehicles (LDDV), light duty gasoline vehicles (LDGV), and motorcycles (MC) were included two-wheels of motorcycles and three-wheels of Tuk-Tuks with 4-stroke engines. The emission factor of $\mathrm{CO}_{2}$ tests were conducted in an emission laboratory (PCD, 2000). The vehicles were further divided into subcategories by vehicle type and fuel type available in Thailand. The details are shown in Table 1. 
Table 1 . The vehicle types and fuel types in the emission laboratory

\begin{tabular}{|c|c|c|c|c|}
\hline $\begin{array}{l}\text { In-use Vehicle } \\
\text { Types }\end{array}$ & $\begin{array}{l}\text { Number } \\
\text { of test }\end{array}$ & $\begin{array}{l}\text { Engines capacity } \\
\text { (cubic centimeters, cc.) }\end{array}$ & Thailand fuel types & Remark types \\
\hline HDDV & 121 & $4,000-12,350$ & Diesel, NGV & Buses \\
\hline LDDV & 199 & $2,200-3,000$ & $\begin{array}{l}\text { Diesel, B2, B5, B20, } \\
\text { B50, B100 }\end{array}$ & $\begin{array}{l}\text { Pick-ups } \\
\text { and Vans }\end{array}$ \\
\hline LDGV & 166 & $1,500-3,200$ & $\begin{array}{l}\text { Gasoline 91, Gasoline 95, } \\
\text { Gasohol 91, Gasohol 95, } \\
\text { LPG, NGV }\end{array}$ & Passenger Cars \\
\hline $\mathrm{MC}$ & 76 & $110-650$ & $\begin{array}{l}\text { Gasoline 91, Gasoline 95, } \\
\text { Gasohol 91, Gasohol 95, } \\
\text { LPG }\end{array}$ & $\begin{array}{l}\text { Motorcycles (2-wheels) } \\
\text { and Tuk-Tuks (3-wheels) } \\
\text { with 4-stroke engines }\end{array}$ \\
\hline
\end{tabular}

\subsection{The Emission Analyses}

The estimation of Emission Factor of $\mathrm{CO}_{2}\left(\mathrm{EF}-\mathrm{CO}_{2}\right)$ came from laboratory tests that simulated actual activities encountered during road transport and controlled for factors such as temperature and humidity. The samples were tested on a chassis dynamometer utilizing standard constant volume sampling (CVS) techniques in which the entire volume of exhaust was produced by the engine and transferred to the tailpipe was captured when diluted by the air. The $\mathrm{CO}_{2}$ concentrations of both the diluted exhaust and the dilution air were measured continually. $\mathrm{CO}_{2}$ samples were collected for analysis using a non-dispersive infrared analyzer. The $\mathrm{CO}_{2}$ concentration and fuel consumption were calculated following standard carbon balance procedures. This study used typical Bangkok driving estimates that represent the most common speed for all vehicle types and total vehicle kilometers traveled (VKT) as the control in the analysis system.

\subsection{The Emission Factor of $\mathrm{CO}_{2}$ Measure}

Determining the $\mathrm{CO}_{2}$ concentration from vehicle emissions involves multiplying data by an appropriate emission factor, which is the total $\mathrm{CO}_{2}$ emission measured divided by the distance traveled estimate (Angiola, 2009), as given by Equation 1:

$$
\left[\mathrm{EF}_{\mathrm{CO} 2}(\mathrm{~g} / \mathrm{km})\right]=\frac{\text { total } \mathrm{CO}_{2} \text { Emission }(\mathrm{g})}{\operatorname{VKT}(\mathrm{km})}
$$

Where the $\mathrm{EF}$ of $\mathrm{CO}_{2}$ is the emission factor of $\mathrm{CO}_{2}$ in grams per kilometer units, total $\mathrm{CO}_{2}$ emission is the concentration from the non-dispersive infrared technique in gram units and VKT is the average vehicle kilometers traveled, as taken from Bangkok driving data, in kilometer units. The emission factor is expressed in grams of $\mathrm{CO}_{2}$ emitted per VKT. Significance levels were calculated at the $95 \%$ level. The study examined the mean and standard deviation of the emission factor of $\mathrm{CO}_{2}$ for each vehicle. The HDDV results were analyzed using an independent $t$-test between two fuel types and all vehicles with all fuel types. The result was subject to analysis of variance (ANOVA) utilizing the statistical package for social science (SPSS) to translate the data into operational solutions.

\section{Results and Discussions}

\subsection{The EF of $\mathrm{CO}_{2}$ Compared with Speed and Fuel Consumption}

The emission factor measures of $\mathrm{CO}_{2}$ in grams per kilometer units are given in Table 2. The average speed in meters per second units and fuel consumption in kilometers per liter were sampled for the 4 vehicle types. The emission factors were significantly different in every vehicle type comparison. The emission of $\mathrm{CO}_{2}$ from vehicles was measured, and a variety of fuel types were used. In-use vehicles of the emission test were separated by vehicle types and fuel types for measured the emission factor. The results show that the average emission factor for HDD vehicles was 1215.5 grams per kilometer, which was higher than that for LDDV, LDGV and MC by 4.2, 6.8 and 25.7 times, respectively. The LDDV reading was higher than that of LDGV and MC by 1.6 and 6.1 times, respectively. The LDGV result was higher than that of MC by 3.8 times. This research shows that the average speed by vehicle type tended to decrease, with HDDV being lower than LDDV, LDGV and MC. However, the fuel consumption tended to increase, with HDDV being higher than LDDV, LDGV and MC, in that order. These results are in accordance with a previous report that the highest emission factor was found in HDDV (Bellasio, 2007). However, in this study show results were as follows: 
Table 2. Emission factor of $\mathrm{CO}_{2}$ on vehicle types, number, speeds and fuel consumption, which were significantly different at $p<0.05$ according to an ANOVA

\begin{tabular}{|c|c|c|c|c|c|}
\hline $\begin{array}{c}\text { Vehicles and Fuel } \\
\text { Types }\end{array}$ & Number of test & $\begin{array}{l}\text { Average Speed } \\
\quad(\mathrm{km} / \mathrm{hr})\end{array}$ & $\begin{array}{c}\text { Fuel } \\
\text { Consumption } \\
(\mathrm{km} / \mathrm{L}) \\
\end{array}$ & $\begin{array}{c}\mathrm{EF}_{\text {average }} \text { of } \\
\mathrm{CO}_{2} \\
(\mathrm{~g} / \mathrm{km}) \\
\end{array}$ & $\begin{array}{l}\text { Standard } \\
\text { Deviation }\end{array}$ \\
\hline HDDV & 121 & & & & \\
\hline Diesel & 104 & 19.3 & 2.4 & 1150.1 & \pm 196.0 \\
\hline NGV & 17 & 21.6 & 1.3 & 1280.9 & \pm 161.8 \\
\hline LDDV & 199 & & & & \\
\hline Diesel & 153 & 21.7 & 9.1 & 307.2 & \pm 74.9 \\
\hline B2 & 8 & 20.9 & 8.0 & 338.1 & \pm 52.8 \\
\hline B5 & 7 & 31.1 & 11.0 & 254.8 & \pm 74.4 \\
\hline B20 & 15 & 25.7 & 9.4 & 301.6 & \pm 83.0 \\
\hline B50 & 15 & 25.7 & 9.5 & 309.5 & \pm 85.4 \\
\hline B100 & 2 & 35.3 & 12.4 & 231.9 & \pm 55.1 \\
\hline LDGV & 166 & & & & \\
\hline Gasoline 91 & 52 & 21.2 & 13.0 & 170.2 & \pm 37.8 \\
\hline Gasoline 95 & 2 & 20.9 & 12.5 & 192.4 & \pm 32.5 \\
\hline Gasohol 91 & 37 & 30.0 & 11.7 & 192.5 & \pm 34.4 \\
\hline Gasohol 95 & 8 & 34.7 & 9.4 & 206.3 & \pm 57.1 \\
\hline LPG & 40 & 22.7 & 12.7 & 156.6 & \pm 20.6 \\
\hline $\mathrm{NGV}$ (as CNG) & 27 & 25.9 & 11.9 & 159.1 & \pm 14.1 \\
\hline $\mathrm{MC}$ & 76 & & & & \\
\hline \multicolumn{6}{|l|}{ Motorcycle } \\
\hline Gasoline 91 & 17 & 32.5 & 37.4 & 38.2 & \pm 7.1 \\
\hline Gasoline 95 & 1 & 34.4 & 38.4 & 41.4 & - \\
\hline Gasohol 91 & 19 & 31.2 & 34.2 & 40.4 & \pm 9.6 \\
\hline Gasohol 95 & 15 & 35.5 & 37.8 & 40.1 & \pm 9.0 \\
\hline \multicolumn{6}{|l|}{ Tuk-Tuks } \\
\hline LPG & 24 & 31.3 & 17.3 & 76.5 & \pm 9.8 \\
\hline
\end{tabular}

1) The HDDV samples showed an average emission factor ranging from 1150.1 to $1280.9 \mathrm{~g} / \mathrm{km}$. The average speed ranged between 19.3 and $21.6 \mathrm{~km} / \mathrm{hr}$, with fuel consumption ranging from 1.3 to $2.4 \mathrm{~km} / \mathrm{L}$, respectively. For diesel and NGV, the EF of $\mathrm{CO}_{2}$ levels was 1150.1 and $1280.9 \mathrm{~g} / \mathrm{km}$, respectively. Graham (2008) reported that HDDVs using NGV fuel had a higher $\mathrm{CO}_{2}$ emission than those using diesel fuels.

2) The LDDV samples had average emission factors in the range of $231.9-338.1 \mathrm{~g} / \mathrm{km}$. The average speeds ranged from 20.9 to $35.3 \mathrm{~km} / \mathrm{hr}$. The fuel consumption ranged between 8.0 and $12.4 \mathrm{~km} / \mathrm{L}$. The $\mathrm{EF}$ of $\mathrm{CO}_{2}$ levels for fuel types diesel, B2, B5, B20, B50 and B100 were 307.2, 338.1, 254.8, 301.6, 309.5 and $231.9 \mathrm{~g} / \mathrm{km}$, respectively. This result agrees with LDDV dynamometer tests using the new European driving cycle (Pelkmans, 2006).

3) The LDGV samples had an average emission factor ranging between 156.6 and $206.3 \mathrm{~g} / \mathrm{km}$. The average speeds ranged from 20.9 to $34.7 \mathrm{~km} / \mathrm{hr}$. The fuel consumption was 9.4 to $13.0 \mathrm{~km} / \mathrm{L}$. The $\mathrm{EF}$ of $\mathrm{CO}_{2}$ levels for fuel type gasoline 91, gasoline 95, gasohol 91, gasohol 95, LPG and NGV were 170.2, 192.4, 192.5, 206.3, 156.6 and $159.1 \mathrm{~g} / \mathrm{km}$, respectively. These results were measured at least two times, and we note that they are less than the average emission factor of LDGV reported by Choi and Frey (2009).

4) The MC samples showed an average emission factor ranging from 38.2 to $76.5 \mathrm{~g} / \mathrm{km}$. The average speed 
ranged from 31.3 to $35.5 \mathrm{~km} / \mathrm{hr}$. and the fuel consumption from 17.3 to $38.4 \mathrm{~km} / \mathrm{L}$. The EF of $\mathrm{CO}_{2}$ levels for the fuel type gasoline 91, gasoline 95, gasohol 91, gasohol 95 and LPG were 38.2, 41.4, 40.4, 40.1 and 76.5 g/km, respectively. Tsai and Weng (2000) reported that $\mathrm{MC}$ had a lower emission factor of $\mathrm{CO}_{2}$ than other vehicles. However, due to economic conditions, the size of these vehicles has tended to increase in developing countries, and we found that overall $\mathrm{CO}_{2}$ emissions from the $\mathrm{MC}$ vehicle type have increased over time.

\subsection{The Comparison of EF of $\mathrm{CO}_{2}$ and Fuel Types}

Fig. 1 shows the average emission factor of $\mathrm{CO}_{2}$ and alternative fuel types as follows: (a) for HDDV, the emission factor for both diesel and NGV were found to differ significantly at the $95 \%$ confidence level using a T-test; (b) for LDDV, the results for all fuel types did not differ significantly at the $95 \%$ confidence level using an ANOVA, but the emission factor of diesel fuel was significantly different compared with that of B2 and B5; (c) for LDGV, all fuel types were significantly different at the $95 \%$ confidence level using an ANOVA, and we found that the emission factor of gasoline 91 was different from gasohol 91 and LPG (note that Gasohol 91 differed from LPG and CNG); (d) for MC, all fuel types differed significantly at the 95\% confidence level using an ANOVA, and the emission factor for gasoline 91 in tuk-tuks was different than when using LPG, gasohol 91 and gasohol 95 .

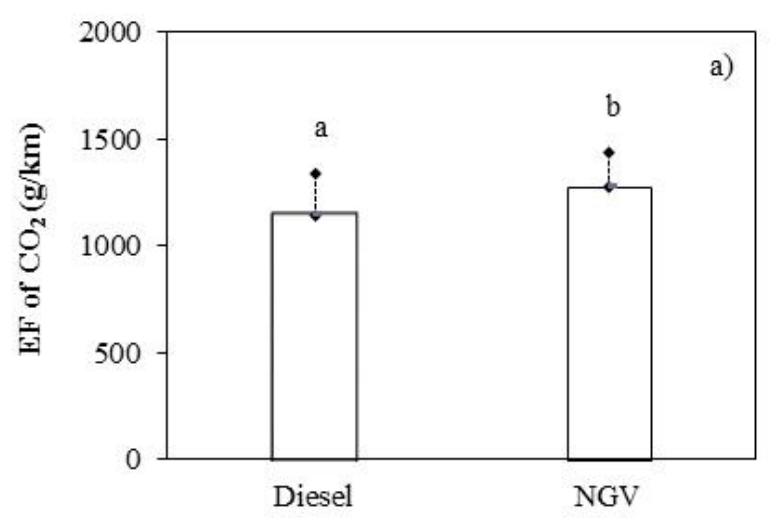

a) Heavy Duty DieselVehicle (HDDV)

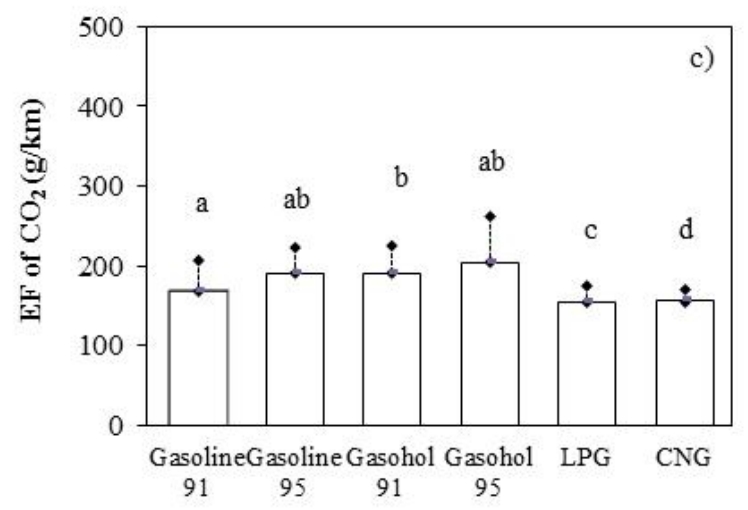

c) Light Duty Gasoline Vehicle (LDGV)

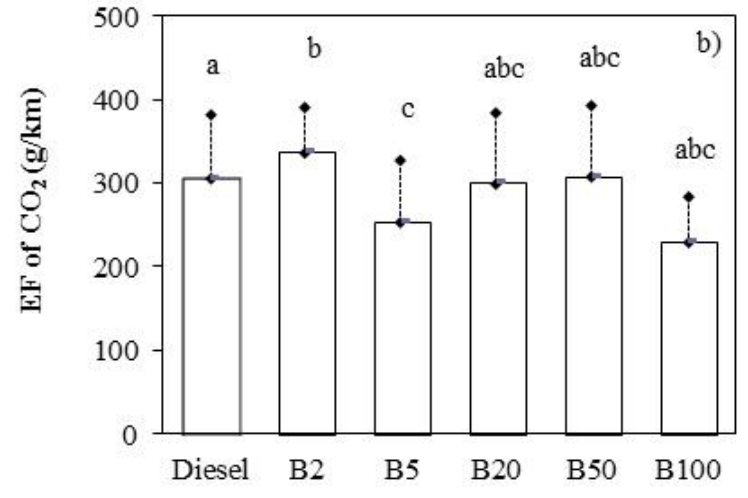

b) Light Duty Diesel Vehicle (LDDV)

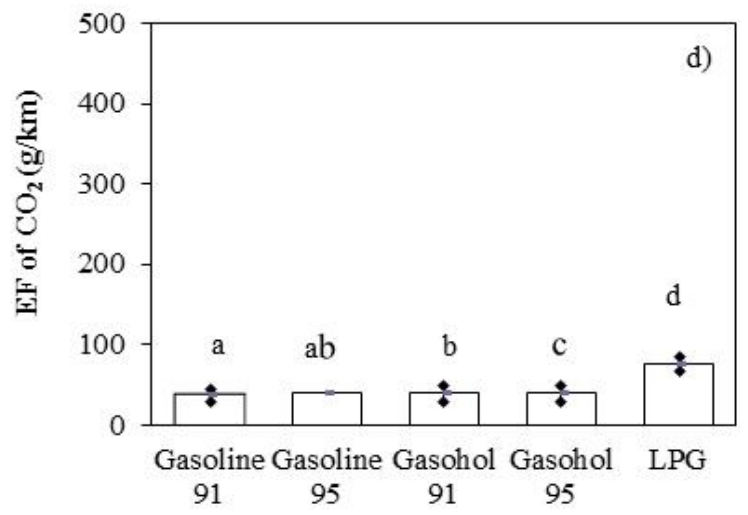

d) Motorcycle (MC)

Figure 1. The average emission factor of $\mathrm{CO}_{2}$ in grams per kilometer by vehicle type: a) HDDV, b) LDDV,

c) LDGV and d) MC, which were significantly different at $p<0.05$ according to an ANOVA

These results illustrate the emission factor of $\mathrm{CO}_{2}$ from motor vehicles measured in kilograms per kilometer. The study used HDDV-, LDDV-, LDGV- and MC-type vehicles and compared our results with those for other emission factor sources. This study will allow organizations and individuals to calculate greenhouse gas effects based on the fuels tested for the emission factor from transport activities. The results tended to agree with 
emission factor studies in Europe (Defra, 2009). The emission factor of $\mathrm{CO}_{2}$ was found to be lower than the guidelines for transportation in the United States of America (USEPA, 2008). The results are shown in Table 3. The emission factor of $\mathrm{CO}_{2}$ from in-use vehicles of Thailand was determined by testing at an automotive emission laboratory. The data obtained in this study can be utilized in estimating greenhouse gas emission from vehicles and evaluating management methodologies to reduce or mitigate the effects.

Table 3. Comparison of emission factors of $\mathrm{CO}_{2}$ and fuel type

\begin{tabular}{|c|c|c|c|c|c|}
\hline & In-use Vehicles & Thailand 1 & $\mathrm{O}_{2}\left(\mathrm{~kg}-\mathrm{CO}_{2} / \mathrm{km}\right)$ & US EPA & EU \\
\hline & by Fuel Type & Tested study & Average EF-CO ${ }_{2}$ & (2008) & (2009) \\
\hline HDDV & & & & & \\
\hline & Diesel & 1.15 & & & \\
\hline & NGV & 1.28 & 1.22 & 2.78 & 0.11 \\
\hline LDDV & & & & & \\
\hline & Diesel & 0.31 & & & \\
\hline & B2 & 0.34 & & & \\
\hline & B5 & 0.26 & & & \\
\hline & $\mathrm{B} 20$ & 0.30 & 0.29 & 0.83 & 0.27 \\
\hline & B50 & 0.31 & & & \\
\hline & $\mathrm{B} 100$ & 0.23 & & & \\
\hline LDGV & & & & & \\
\hline & Gasoline 91 & 0.17 & & & \\
\hline & Gasoline 95 & 0.19 & & & \\
\hline & Gasohol 91 & 0.19 & & & \\
\hline & Gasohol 95 & 0.21 & 0.18 & 0.58 & 0.21 \\
\hline & LPG & 0.16 & & & \\
\hline & $\mathrm{NGV}$ (as $\mathrm{CNG}$ ) & 0.16 & & & \\
\hline $\mathrm{MC}$ & & & & & \\
\hline & Gasoline 91 & 0.04 & & & \\
\hline & Gasoline 95 & 0.04 & & & \\
\hline & Gasohol 91 & 0.04 & 0.048 & 0.27 & 0.11 \\
\hline & Gasohol 95 & 0.04 & & & \\
\hline & LPG & 0.08 & & & \\
\hline
\end{tabular}

\section{Conclusions}

This study shows that the EF-CO $\mathrm{CO}_{2}$ of HDDV was 1215.5 grams per kilometer, which is higher than the output for LDDV, LDGV and MC by approximately 4.2, 6.8 and 25.7 times, respectively. The LDDV output was higher than that for LDGV and MC, by 1.6 and 6.1 times, respectively. The LDGV was higher than MC by 3.8 times. These results can be estimated the $\mathrm{CO}_{2}$ emission from transport section and used in Thailand to promote better efficiency to mitigate greenhouse gas emissions from vehicles.

\section{Acknowledgements}

The work was supported by the Interdisciplinary Program of Environmental Science, Graduate School, Chulalongkorn University and the Automotive Emission Laboratory, Air Quality and Noise Management Bureau, Pollution Control Department, Ministry of Natural Resources and Environment, Thailand.

\section{References}

Angiola, A., Dawidowski, L., Gomez, D., \& Osses, M. (2009). On-road traffic emissions in megacity. Atmospheric Environment, 31, 1-11. http://dx.doi.org/10.1016/j.atmosenv.2009.11.004 
Bellasio, R., Bianconi, R., Corda, G., \& Cucca, P. (2007). Emission inventory for the road transport sector in Sardinia (Italy). Atmospheric Environment, 41, 677-691. http://dx.doi.org/10.1016/j.atmosenv.2006.09.017

Choi, H., \& Frey, H. (2009). Light duty gasoline vehicle emission factors at high transient and constant speeds for short road segments. Transportation Research Part D, 14, 610-614. http://dx.doi.org/10.1016/j.trd.2009.09.001

Defra. (2009). Guidelines to DEFRA'S/DECC's Greenhouse Gas Conversion Factors for company reporting. Department for Environment Food and Rual Affair. Retrieved from http://www.defra.gov.uk/environment/economy/ business-efficiency/reporting

Graham, L. A., Rideout, G., Rosenblatt, D., \& Hendren, J. (2008). Greenhouse gas emissions from heavy-duty vehicles. Atmospheric Environment, 42, 4665-4681. http://dx.doi.org/10.1016/j.atmosenv.2008.01.049

Intergovernmental Panel on Climate Change. (1995). Greenhouse Gas Inventory, Reference Manual. IPCC Guideline for National Greenhouse Gas Inventories: Vil. III. IPCC WG I Technical Support Unit, London. Meteorological Center, London, UK. p. 364.

Intergovernmental Panel on Climate Change. (2007). Intergovernmental Panel on Climate Change. Climate Change 2007: Impacts, Adaptation and Vulnerability. Cambridge University Press. United State. Retrieved from http://www.meteotrentino.it/clima/pdf/rapporti_meteo/IPCC_Impacts_Adaptation_and_Vulnerability

Pelkmans, L. (2006). Comparison of on-road emissions with emissions measured on chassis dynamometer test cycles. Transportation Research Part D, 11, 233-241. http://dx.doi.org/10.1016/j.trd.2006.04.001

Pollution Control Department. (2000). Automotive emission laboratory, Ministry of Natural Resources and Envronment, Bangkok.

Tsai, J. H., Hsu, Y. C., \& Weng, H. C. (2000). Air pollutant emission factors from new and in-use motorcycles. Atmospheric Environment, 34, 4747-4754. http://dx.doi.org/10.1016/S1352-2310(00)00270-3

USEPA. (2008). Optional Emissions from Commuting, Business Travel and Product Transport, Washington DC., USA. Retrieved from http://www.epa.gov/climateleadership/documents/resources/commute_travel_product

Wang, H., Fu, L., Zhou, Y., Du, X., \& Ge, W. (2010). Trends in vehicular emissions in Chinas mega cities from1995 to 2005. Environmental Pollution, 158, 394-400. http://dx.doi.org/10.1016/j.envpol.2009.09.002

Warapetcharayut, P., \& Paw-armart, I. (2003). Emission Factor Development in Thailand. Automotive Air Pollution Section. Thailand. Retrieved from http://www.cleanairinitiative.org/portal/node/3275 